\title{
Differential expression of six genes in fat-type Hungarian Mangalica and other pigs
}

\author{
Károly Tempfli ${ }^{1}$, Barbara Kiss ${ }^{1}$, Klaudia Szalai ${ }^{1}$, Zoltán Simon $^{2}$, László Pongrácz ${ }^{1}$, and \\ Ágnes Bali Papp ${ }^{1}$ \\ ${ }^{1}$ Department of Animal Sciences, Széchenyi István University, Mosonmagyaróvár, 9200, Hungary \\ ${ }^{2}$ Olmos and Tóth Ltd., Debrecen, 4025, Hungary \\ Correspondence to: Károly Tempfli (tempfli.karoly@ sze.hu)
}

Received: 26 January 2016 - Revised: 31 May 2016 - Accepted: 7 June 2016 - Published: 14 June 2016

\begin{abstract}
In order to identify potential variances in gene expression of phenotypically different pig breeds, six fat-metabolism-related genes were analyzed in backfat and muscle tissues of fat-type Mangalica (MAN), Mangalica $\times$ Duroc $(\mathrm{MD})$, and lean-type Hungarian Large White (HLW) and Pietrain $\times$ Duroc (PD) pigs by means of quantitative reverse transcription PCR (qRT-PCR). Higher $(P<0.05)$ adipocyte fatty-acid-binding protein $(A-$ $F A B P$ ) expression was observed in backfat and muscle tissues of purebred and crossbred MAN than in those of HLW and PD. In all breeds and crosses, adiponectin $(A D I P O Q)$ was predominantly expressed in backfat at a similar level $(P>0.05)$, whereas muscle $A D I P O Q$ expression was highest $(P<0.05)$ in MAN and MD. Levels of fatty acid synthase (FASN) mRNA were greatest in MAN, moderate in MD, and lowest in HLW and PD backfat and muscle. The fat mass and obesity-associated gene (FTO) was more abundant in MAN and MD backfat, whereas muscle expressions did not differ $(P>0.05)$ between breeds. Regarding leptin $(L E P)$ expression, MAN produced the greatest levels in backfat, while HLW produced the lowest. In muscle, highest $L E P$ was detected in MAN and MD. Between groups, perilipin 2 (PLIN2) was expressed similarly in backfat; however, PLIN2 was more abundant in muscle of MAN and MD than in that of HLW and PD. Differences in gene expression can contribute to the development of the characteristic fatty phenotype in MAN pigs. The identification of differentially expressed genes facilitates targeted sequencing and genotyping efforts for further studies.
\end{abstract}

\section{Introduction}

The hypothesis of the study was that the expression of the six selected fat-metabolism-related genes is different between the experimental breeds and crosses that differ characteristically in fat content, growth rate, and body composition. The indigenous Hungarian fat-type Mangalica (MAN) provides unique possibilities to compare gene expression patterns with commercial modern pig breeds selectively developed for lean pork production. By the possible identification of genes with major expression differences, this study aimed to generate valuable information for the explanation of the genetic background behind the spectacularly unique fatty phenotype of MAN.

The MAN belongs to the very limited number of fat-type pig breeds that still exist today, with extreme fat content in carcass that reaches up to $60-70 \%$. Lean meat, on the other hand, generally contains less than $40 \%$. The curlyhaired MAN breed came close to extinction in the 1970s due to changing customer expectations (i.e., increased need for leaner pork) and the emergence of meat-type breeds (Rátky et al., 2013). Currently, the MAN population is being restored and is getting intense attention in quality pork production due to its extended intramuscular fat (IMF) deposition. The IMF content is one of the most important determining factors regarding meat quality as it is positively associated with savoriness and tenderness (Fernandez et al., 1999). To improve growth and lean meat percentage of progenies, Duroc boars are occasionally mated with MAN sows for commercial fattening pig production (Tempfli et al., 2015). In the cross breedings, Duroc provides increased meat production while virtually maintaining meat quality and marbled pork. 
Table 1. BFT, LD, LW, ADG, and age in the analyzed groups $(n)$, presented as mean $\pm \mathrm{SD}$

\begin{tabular}{lcccc}
\hline Trait* & MAN (12) & MD (12) & HLW (10) & PD (4) \\
\hline BFT (mm) & $50.7 \pm 5.5$ & $43.5 \pm 5.1$ & $34.3 \pm 5.1$ & $35.1 \pm 5.8$ \\
LD (mm) & $46.3 \pm 5.0$ & $53.8 \pm 5.3$ & $55.4 \pm 4.7$ & $63.3 \pm 6.3$ \\
LW (kg) & $126 \pm 8.3$ & $131 \pm 8.1$ & $121 \pm 8.5$ & $124 \pm 9.0$ \\
ADG (g day $\left.{ }^{-1}\right)$ & $592 \pm 67$ & $707 \pm 63$ & $755 \pm 71$ & $772 \pm 83$ \\
Age (day) & $262 \pm 12$ & $229 \pm 10$ & $197 \pm 14$ & $188 \pm 16$ \\
\hline * BFT: backfat thickness; LD: loin diameter; LW: live weight; ADG: average daily gain during \\
fattening.
\end{tabular}

The Hungarian Large White (HLW) breed was included in the study because it is one of the most common maternal breeds used in Hungary. HLW is predominantly known for good reproductive performance while producing sufficient lean meat. The Pietrain and Duroc breeds, on the other hand, are outstanding in lean meat production; however, they generally lag behind HLW regarding reproductive traits.

Just a few decades ago, adipose tissue was considered merely as an inert depot to store lipids as an energy source; however, adipose tissue is presently acknowledged as an endocrinologically active tissue that greatly contributes to the regulation of several biological processes, including energy expenditure or feed intake through releasing hormones such as leptin or adiponectin (Matsubara et al., 2002). In order to compare the expression of some physiologically important regulating factors at the mRNA level, six genes were selected for analysis based on their candidate roles in controlling feed intake, lipogenesis, fatty acid transportation, or intramuscular fat accumulation (Cho al., 2011; Chen et al., 2013; Cirera et al., 2014).

\section{Materials and methods}

\subsection{Experimental animals and sampling}

Four different breeds and crosses of various origin were chosen with characteristically different body fat content and body composition: purebred Blonde MAN $(n=12)$, Mangalica $\times$ Duroc (MD) $(n=12)$, HLW $(n=10)$, and Pietrain $\times$ Duroc (PD) $(n=4)$. Backfat (subcutaneous fat from the fourth rib) and muscle (m. levator scapulae) samples were collected from gilts at a local abattoir and then put into RNase-free freezer vials within $45 \mathrm{~min}$ after slaughter. Filled vials were immediately submerged in liquid $\mathrm{N}_{2}$ to avoid extended RNase exposure and degradation. Samples were transported and stored in liquid $\mathrm{N}_{2}$ containers pending processing. Traits (BFT: backfat thickness; LD: loin diameter; LW: live weight; ADG: average daily gain during fattening; and age) of the experimental animals were also recorded (Table 1). When experimenting with MAN and modern commercial breeds, an ever-emerging question is when to compare the animals - at identical weight or age - because it is practically not feasible to acquire both at the same time, even under identical housing and feeding conditions. In this study, animals were selected to be of similar live weight rather than of similar age; however, age can also be an important factor affecting gene expression and protein levels (Christoffersen et al., 2010; Ren et al., 2005). Further studies with modified experimental design are needed to assess age-dependent changes in MAN and other breeds.

\subsection{RNA isolation, qRT-PCR, and statistical analysis}

Total RNA was isolated using TRIzol Reagent (Thermo Fisher Scientific, USA) and 1-bromo-3-chloropropane (VWR International, USA). Three isolations were carried out for every experimental animal and for each tissue. Samples (150-200 mg) were processed with TissueLyser LT (Qiagen, Germany) for each isolation. Concentration of RNA was determined by means of a NanoDrop 2000 spectrophotometer (Thermo Fisher Scientific). Integrity of RNA diluted in DEPC-treated nuclease-free water was verified by agarose gel electrophoresis and ethidium bromide staining (Fig. S1 in the Supplement). The RNA yields greatly varied between tissues; backfat RNA yields were typically below $200 \mathrm{ng} \mu \mathrm{L}^{-1}$, whereas muscle RNA yields were approximately $1.5 \mu \mathrm{g} \mu \mathrm{L}^{-1}$. To avoid potential DNA contamination, isolated RNA was treated with RQ1 RNase-free DNase (Promega, USA) following the manufacturer's instructions. According to the manufacturer's recommendations, $1 \mu \mathrm{g}$ of each total RNA sample was reverse-transcribed using an iScript cDNA synthesis kit (Bio-Rad, USA) containing a blend of oligo $(\mathrm{d} T)$ and random hexamer primers. Gene expression was quantified by qPCR using SsoFast EvaGreen Supermix (Bio-Rad) and the $2^{-\Delta \Delta C t}$ method. Reactions were performed in triplicates on a CFX96 real-time PCR detection system (Bio-Rad) using clear plates. In the experiments, $\beta$ actin $(A C T B)$ was used as a reference gene (Luo et al., 2009). The sequences of the primers applied, product lengths, accession numbers, relevant annealing temperatures, and efficiency of PCRs are shown in Table 2. For each gene, the efficiency was determined by 10 -fold serial dilutions ("standards") of the PCR products. Every run contained no template controls (NTCs) for the analyzed and the reference genes as well. The NTCs were accepted as negative with threshold cycles over 35 , as quantitation cycles were always 
prior to this cycle. Thermal profile was as follows: one initial denaturation cycle at $95^{\circ} \mathrm{C}$ for $5 \mathrm{~min}$, followed by 40 twostep cycles of $95^{\circ} \mathrm{C}$ for $30 \mathrm{~s}$ and gene-specific annealing temperature (Table 2) for $30 \mathrm{~s}$. After the last cycle, melting curve analysis was performed (from 65 to $95^{\circ} \mathrm{C}$, with $0.5^{\circ} \mathrm{C}$ increments) to verify specificity of the amplified products.

Expression data were analyzed by one-way ANOVA (Tukey's) test in SPSS v.16 for Windows (SPSS Inc.) and means were considered significantly different at $P<0.05$. Pearson's correlation between gene expression and production traits was also determined. Throughout the study, animal handling and sampling were conducted in accordance with the standards recommended by Directive 2010/63/EU.

\section{Results and discussion}

The expression of six fat-metabolism-related genes was analyzed by means of quantitative reverse transcription PCR (qRT-PCR), and $\beta$-actin-normalized expressions were compared between different groups of pigs. The length of qPCR products was checked by agarose gel electrophoresis to identify DNA contamination or possible alternative splicing events; however, no unexpected products or splicing variants were detected.

\subsection{A-FABP expression}

In every breed and cross, adipocyte fatty-acid-binding protein $(A-F A B P)$ (or $F A B P 4)$ was predominantly active in backfat and less abundant in muscle $(P<0.05)$. Similar distribution between muscle and adipose tissue has formerly been described in MD crossbred pigs (Tempfli et al., 2015). The four analyzed groups appeared to be clearly separated based on the $A-F A B P$ transcript level: higher $(P<0.05)$ expression was detected in adipose as well as in muscle tissues of MAN and MD than in those of HLW and PD (Table 3). $A-F A B P$ plays a central role in intracellular desorption and transport of fatty acids from the plasma membrane to the cytoplasm (the site of triacylglycerol and phospholipid synthesis) and to the mitochondria (the site of beta oxidation) and is considered a candidate gene for fat deposition in swine (Chmurzynska, 2006). Consistent with the present results, Zhao et al. (2009) detected higher A-FABP transcript levels in muscle of the local Chinese Wujin, a fatty pig breed compared to the leaner Landrace, indicating that leaner breeds can transport fewer fatty acids through intracellular trafficking, resulting in less extended IMF. Expression of A-FABP was positively correlated with IMF content in purebred and Large White crossbred Chinese Laiwu Black pigs, where $A-F A B P$ transcript levels increased rapidly with the body weight until $60-70 \mathrm{~kg}$ and then remained at high levels in both breeds analyzed (Chen et al., 2013). In the present study, no measurements were taken to determine IMF content; however, the MAN is well known for marbled pork production and is generally characterized by largely elevated IMF com- pared to other breeds (Holló et al., 2009; Koncz et al., 2014). Furthermore, BFT is positively correlated with IMF content in pigs (Jacyno et al., 2015), and greatest BFT was measured in the MAN group (Table 1).

$A-F A B P$ was found to be upregulated in a selected highfat line of Duroc pigs when compared to the low-fat Duroc group (Canovas et al., 2010). Differential A-FABP expression was also detected between Berkshire and Yorkshire pigs, where highest levels were measured in Berkshire, a breed well known for marbled pork production and IMF deposition (Cho et al., 2011). No such correlations were identified in Large White $\times$ Landrace animals (Gerbens et al., 2001); however, $A-F A B P$ content in muscle was remarkably greater in pigs with increased IMF than in those with low IMF content; furthermore, positive correlation was identified between $A-F A B P$ level and adipocyte number and lipid content (Damon et al., 2006). Similarly, a moderately strong positive correlation was observed between BFT and $A-F A B P$ levels in the present study (Table 4), whereas LD and ADG were negatively correlated to $A-F A B P$ expression.

In cases where a lack of correlation was detected between $A-F A B P$ mRNA and protein levels, an occurrence of posttranscriptional protein-protein interaction mechanisms was hypothesized (Damon et al., 2006). In the present study, AFABP mRNA levels of purebred and Duroc crossbred MAN were highest $(P<0.05)$ in both backfat and muscle; however, protein abundance was not investigated. Further experiments are needed to analyze the relationship between gene expression and actual protein levels in MAN and MD.

\subsection{ADIPOQ expression}

Of all six genes analyzed, adiponectin $(A D I P O Q)$ was most abundant in backfat, while its expression in muscle was found to be the lowest (Table 3); this is not surprising since $A D I P O Q$ is secreted almost exclusively by adipocytes. $A D I P O Q$ was previously shown to have elevated expression in MD fat compared to muscle (Tempfli et al., 2015). No significant differences were detected between groups in $A D I P O Q$ backfat level; however, muscle expression was remarkably higher $(P<0.05)$ in MAN and MD than in the other groups (Table 3 ). Regarding the distinctive muscle $A D I P O Q$ expression, the role of intramuscular fat cells is to be emphasized. According to Ding et al. (2004) ADIPOQ can be hardly detectable in muscle samples of breeds that do not deposit excessive IMF, as it can be an exclusive source of $A D I P O Q$ transcripts in muscle. Daniele et al. (2008) detected significant differences in subcutaneous adipose tissue $A D I P O Q$ expression of Large White and fat-type Casertana pigs, with higher levels in lean-type Large White. This is consistent with human studies, where ADIPOQ hormone levels have been inversely related to body fat content (Matsubara et al., 2002). Lord et al. (2005) observed similar patterns in adipose tissue $A D I P O Q$ expression of Upton-Meishan (excessive fat content) and Large White pigs. Interestingly, in 
Table 2. Primer sequences, length of PCR products, gene accession numbers, annealing temperatures $\left(T_{\mathrm{a}}\right)$, and PCR efficiency (mean $\pm \mathrm{SD}$ )

\begin{tabular}{|c|c|c|c|c|c|}
\hline Gene & Primer sequence $\left(5^{\prime}-3^{\prime}\right)$ & Length (bp) & Accession number & $T_{\mathrm{a}}\left({ }^{\circ} \mathrm{C}\right)$ & Efficiency (\%) \\
\hline$A-F A B P^{\mathrm{d}}$ & $\begin{array}{l}\text { F: CAG GAA AGT CAA GAG CAC CA } \\
\text { R: TCG GGA CAA TAC ATC CAA CA }\end{array}$ & 227 & AJ416020 & 58 & $92.2 \pm 3.1$ \\
\hline$A D I P O Q^{\mathrm{a}}$ & $\begin{array}{l}\text { F: CGA GAA GGG TGA GAA AGG AG } \\
\text { R: TAG GCG CTT TCT CCA GGT TC }\end{array}$ & 123 & AY135647 & 55 & $84.7 \pm 4.3$ \\
\hline$F A S N^{\mathrm{d}}$ & $\begin{array}{l}\text { F: AGC CTA ACT CCT CGC TGC AAT } \\
\text { R: TCC TTG GAA CCG TCT GTG TTC }\end{array}$ & 196 & AY183428 & 58 & $95.7 \pm 5.7$ \\
\hline$F T O^{\mathrm{a}}$ & $\begin{array}{l}\text { F: CAG CAG TGG CAG CTG AAA TA } \\
\text { R: TGA CAA GGT CCC GAA ATA AG }\end{array}$ & 133 & AM905422 & 54 & $89.4 \pm 4.0$ \\
\hline$L E P^{\mathrm{a}}$ & $\begin{array}{l}\text { F: TGA CAC CAA AAC CCT CAT CA } \\
\text { R: ATG AAG TCC AAA CCG GTG AC }\end{array}$ & 102 & NM_213840 & 55 & $98.8 \pm 5.3$ \\
\hline$P L I N 2^{\mathrm{b}}$ & $\begin{array}{l}\text { F: ATC ACT GAG GTG GTG GAC AAG } \\
\text { R: GCT GCA TCA TCC GAC TTC C }\end{array}$ & 112 & NM_214200 & 59 & $92.6 \pm 6.5$ \\
\hline$A C T B^{\mathrm{c}}$ & $\begin{array}{l}\text { F: CCA GGT CAT CAC CAT CGG } \\
\text { R: CCG TGT TGG CGT AGA GGT }\end{array}$ & 158 & AY550069 & - & $91.3 \pm 7.2$ \\
\hline
\end{tabular}

${ }^{\mathrm{a}}$ As in Cirera et al. (2014); ${ }^{\mathrm{b}}$ as in Davoli et al. (2011); ${ }^{\mathrm{c}}$ as in Luo et al. (2009); ${ }^{\mathrm{d}}$ as in Zhao et al. (2009).

Table 3. Normalized fold expression (mean $\pm \mathrm{SEM}$ ) of A-FABP, ADIPOQ, FASN, FTO, LEP, and PLIN2 genes in backfat and muscle tissues of MAN, MD, HLW, and PD pigs.

\begin{tabular}{llcccc}
\hline Gene & Tissue & MAN & MD & HLW & PD \\
\hline \multirow{2}{*}{$A-F A B P$} & Backfat & $6.63 \pm 0.41^{\mathrm{a}}$ & $6.08 \pm 0.35^{\mathrm{a}}$ & $4.45 \pm 0.25^{\mathrm{b}}$ & $4.53 \pm 0.37^{\mathrm{b}}$ \\
& Muscle & $1.00 \pm 0.08^{\mathrm{a}}$ & $0.87 \pm 0.08^{\mathrm{a}}$ & $0.54 \pm 0.10^{\mathrm{b}}$ & $0.55 \pm 0.12^{\mathrm{b}}$ \\
\hline \multirow{2}{*}{ ADIPOQ } & Backfat & $36.02 \pm 2.27$ & $33.40 \pm 2.43$ & $35.83 \pm 2.50$ & $34.12 \pm 3.26$ \\
& Muscle & $0.54 \pm 0.03^{\mathrm{a}}$ & $0.51 \pm 0.04^{\mathrm{a}}$ & $0.23 \pm 0.02^{\mathrm{b}}$ & $0.25 \pm 0.04^{\mathrm{b}}$ \\
\hline \multirow{2}{*}{ FASN } & Backfat & $8.91 \pm 0.39^{\mathrm{a}}$ & $7.04 \pm 0.44^{\mathrm{b}}$ & $5.43 \pm 0.31^{\mathrm{c}}$ & $5.57 \pm 0.39^{\mathrm{c}}$ \\
& Muscle & $0.79 \pm 0.05^{\mathrm{a}}$ & $0.73 \pm 0.05^{\mathrm{a}}$ & $0.44 \pm 0.03^{\mathrm{b}}$ & $0.39 \pm 0.04^{\mathrm{b}}$ \\
\hline \multirow{2}{*}{ FTO } & Backfat & $3.41 \pm 0.25^{\mathrm{a}}$ & $3.67 \pm 0.23^{\mathrm{a}}$ & $2.35 \pm 0.15^{\mathrm{b}}$ & $2.43 \pm 0.28^{\mathrm{b}}$ \\
& Muscle & $0.64 \pm 0.05$ & $0.58 \pm 0.07$ & $0.53 \pm 0.06$ & $0.48 \pm 0.10$ \\
\hline LEP & Backfat & $12.40 \pm 0.85^{\mathrm{a}}$ & $8.11 \pm 0.61^{\mathrm{b}}$ & $5.53 \pm 0.47^{\mathrm{c}}$ & $6.83 \pm 0.58^{\mathrm{bc}}$ \\
& Muscle & $4.48 \pm 0.37^{\mathrm{a}}$ & $3.99 \pm 0.42^{\mathrm{a}}$ & $2.10 \pm 0.18^{\mathrm{b}}$ & $2.41 \pm 0.33^{\mathrm{b}}$ \\
\hline PLIN2 & Backfat & $1.23 \pm 0.08$ & $1.29 \pm 0.15$ & $1.13 \pm 0.12$ & $1.21 \pm 0.18$ \\
& Muscle & $2.44 \pm 0.15^{\mathrm{a}}$ & $2.30 \pm 0.17^{\mathrm{a}}$ & $1.43 \pm 0.14^{\mathrm{b}}$ & $1.52 \pm 0.21^{\mathrm{b}}$ \\
\hline
\end{tabular}

a, b, c Within rows, different letters indicate significant $(P<0.05)$ difference.

the present study this difference was not observed between backfat $A D I P O Q$ mRNA levels of MAN and MD and leaner HLW or PD pigs. However, muscle $A D I P O Q$ expression was in positive correlation with BFT, and in negative correlation with LD and ADG; no significant correlation was detected between backfat $A D I P O Q$ expression and BFT, LD, or ADG (Table 4).

A potential explanation for this is that fatter pigs express higher levels of $A D I P O Q$ in visceral fat than in subcutaneous fat (Lord et al., 2005). By means of muscle transcriptome profiling, Canovas et al. (2010) detected elevated $A D I P O Q$ expression in high-fat Duroc compared to low-fat Duroc animals, which is consistent with the findings reported in this study. As Canovas et al. (2010) also indicated, these results are not in agreement with the observations in humans that fatty acid oxidation is reduced in obese individuals. Paradoxically, $A D I P O Q$ seems to be more expressed in muscle tissue of obese pigs without decreasing lipid accumulation via beta oxidation, which can be partly explained by the lower expres- 
Table 4. Correlations between gene expression and production traits of the experimental animals.

\begin{tabular}{llccc}
\hline Gene & Tissue & \multicolumn{3}{c}{ Traits* } \\
\cline { 3 - 5 } & & BFT & LD & ADG \\
\hline \multirow{2}{*}{ A-FABP } & Backfat & 0.60 & -0.31 & -0.24 \\
& Muscle & 0.47 & -0.35 & $\mathrm{~ns}$ \\
\hline \multirow{2}{*}{ ADIPOQ } & Backfat & $\mathrm{ns}$ & $\mathrm{ns}$ & $\mathrm{ns}$ \\
& Muscle & 0.44 & -0.24 & -0.31 \\
\hline FASN & Backfat & 0.42 & -0.20 & -0.26 \\
& Muscle & 0.31 & -0.22 & -0.29 \\
\hline \multirow{2}{*}{ FTO } & Backfat & 0.53 & $\mathrm{~ns}$ & $\mathrm{~ns}$ \\
& Muscle & $\mathrm{ns}$ & $\mathrm{ns}$ & -0.23 \\
\hline \multirow{2}{*}{ LEP } & Backfat & 0.56 & -0.48 & -0.33 \\
& Muscle & 0.45 & -0.18 & -0.27 \\
\hline PLIN2 & Backfat & $\mathrm{ns}$ & $\mathrm{ns}$ & $\mathrm{ns}$ \\
& Muscle & 0.35 & -0.15 & -0.21 \\
\hline
\end{tabular}

* BFT: backfat thickness; LD: loin diameter; ADG: average daily gain during fattening; ns: correlation is not significant $(P>0.05)$.

sion of $A D I P O Q$ receptors (Lord et al., 2005; De Rosa et al., 2013).

\subsection{FASN expression}

The fatty acid synthase gene (FASN) was most active in adipose tissue in all groups. Its expression in backfat was highest in MAN, moderate in MD, and lowest in HLW and PD (Table 3). Muscle expression of MAN and MD did not differ significantly; however, both were higher $(P<0.05)$ compared to HLW and PD. Correlation analysis showed similar patterns to expression differences, as fat and muscle FASN levels were correlated positively to BFT and negatively to LD and ADG (Table 4).

FASN encodes for a crucial enzyme complex of lipogenesis that catalyzes the synthesis of palmitate (a long-chain saturated fatty acid) from acetyl-CoA and malonyl-CoA. Based on the differences in FASN expression, it was concluded that lipid synthesis is more active in MAN and MD than in HLW or PD. Higher muscle lipid synthesis can largely contribute to IMF deposition. Similar patterns of FASN expression were observed when Wujin pigs were compared to the leaner Landrace (Zhao et al., 2009), and when Italian Duroc was compared to Italian Large White (Braglia et al., 2014), underlining the greater potential of some breeds for accumulation of fat in muscle.

\subsection{FTO expression}

Differential fat mass and obesity-associated gene (FTO) expression was observed in backfat of MAN and MD as well as HLW and PD (Table 3). Muscle FTO levels did not differ significantly $(P>0.05)$. The level of $F T O$ in fat was significantly correlated to BFT but not to LD or ADG, whereas muscle levels were in negative correlation with ADG but not with BFT or LD (Table 4).

FTO is known to be involved in the regulation of body weight and adiposity, and was found differentially expressed between Göttingen minipigs and lean production pigs (Cirera et al., 2014); however, expression was not as largely differentiated between subcutaneous backfat and muscle tissues compared to present breeds and crosses. Similar to the results presented here, more definite differences were observed in the expression of FTO in muscle and backfat tissues of the Taihu-based Chinese pig breed Suzhong (Fu et al., 2013). Higher FTO expression in MAN and MD adipose tissue confirmed that elevated FTO level contributes to the development of the fattier phenotype. Targeted sequencing of the MAN FTO gene is needed to identify the causes and the genetic background (e.g., potential specific alleles modifying transcription factor binding sites) of elevated expression.

\subsection{LEP expression}

Regarding backfat tissue, highest $(P<0.05)$ leptin $(L E P)$ expression was detected in MAN, followed by MD and PD, whereas HLW was characterized by the lowest expression levels (Table 3). In muscle, MAN and MD produced more $(P<0.05) L E P$ compared to HLW and PD. Correlation analysis revealed positive correlation between BFT and LEP levels in fat and muscle and negative correlation with LD and ADG (Table 4).

Georgescu et al. (2014) observed similarly increased LEP expression in MAN compared to purebred Duroc and other commercial lean production pigs. LEP (a hormone mainly secreted by adipocytes) plays pivotal roles in controlling feed intake and energy homeostasis of pigs through hypothalamic areas associated with the regulation of appetite (Barb et al., 2001). A continuous increase in $L E P$ levels can lead to $L E P$ resistance and consequently to impaired appetite suppression and unmitigated food intake, which is a potential mechanism responsible for developing the obese phenotype in MAN. Furthermore, elevated $L E P$ levels can lead to disturbances in luteinizing hormone (LH) secretion, ovulatory failure, and deterioration in reproductive functions (Brüssow et al., 2008; Mitchell et al., 2005). High LEP expression and subsequent resistance are potential factors behind the poor reproductive performance of MAN, with average litter sizes of 5-7 piglets (Tempfli et al., 2011).

\subsection{PLIN2 expression}

Of the analyzed genes, only the PLIN2 (perilipin 2 or adipocyte differentiation-related protein) gene was detected with higher normalized expression in muscle compared to backfat. Muscle PLIN2 levels were in positive correlation with BFT but in negative correlation with LD and ADG (Ta- 
ble 4). There was no significant $(P>0.05)$ difference between PLIN2 expressions in backfat of any of the analyzed groups. Nevertheless, muscle levels were different $(P<0.05)$ for MAN and MD as well as for HLW and PD (Table 3). Elevated PLIN2 expression in muscle was therefore concluded to associate with IMF accumulation. Similar patterns of PLIN2 activity were presented by Davoli et al. (2011); however, in their study a slightly higher PLIN2 level was observed in backfat compared to that in muscle, which can be attributed to the different selection of experimental muscle tissues.

\section{Conclusion}

In conclusion, the expression of the analyzed fatmetabolism-related genes showed very similar patterns: the fatty MAN generally produced highest levels, and was followed by MD, while lowest levels were detected in lean-type groups, HLW and PD. Due to these similar patterns of gene expression, similar results were also derived from the correlation analysis for most of the genes. It needs to be indicated that the correlation coefficients generated from the analysis of expression levels and production traits of the experimental animals are most certainly and largely affected by characteristic breed differences and not only by expression differences. Based on the present results and available literature data, it seems that particular pig breeds, although of very distinct origin, develop the obese phenotype via similar mechanisms and pathways, in which the genes analyzed in the current study apparently play central roles and undergo analogous transcriptional regulations. It is also worth mentioning that, due to substantial anatomical similarities between humans and pigs, obese swine breeds can provide new models for obesity studies, where porcine gene expression results can also be relevant from a human medicinal point of view.

\section{The Supplement related to this article is available online at doi:10.5194/aab-2-259-2016-supplement.}

Author contributions. K. Tempfli, K. Szalai, and Z. Simon participated in sampling and data collection. K. Tempfli, B. Kiss, K. Szalai, and L. Pongrácz carried out the laboratory analyses. K. Tempfli and L. Pongrácz were responsible for the statistical analyses. Á. Bali Papp designed and coordinated the experiments and provided supervision. K. Tempfli and Á. Bali Papp prepared the manuscript with contributions from all co-authors.

Acknowledgements. This research was supported by the European Union and the government of Hungary, co-financed by the European Social Fund in the framework of the TÁMOP 4.2.4.A/2-11-1-2012-0001 "National Excellence Program".
Edited by: S. Maak

Reviewed by: three anonymous referees

\section{References}

Barb, C. R., Hausman, G. J., and Houseknecht, K. L.: Biology of leptin in the pig, Domest. Anim. Endocrin., 21, 297-317, 2001.

Braglia, S., Zappaterra, M., Zambonelli, P., Comella, M., Dall'Olio, S., and Davoli, R.: Analysis of g.265T > C SNP of fatty acid synthase gene and expression study in skeletal muscle and backfat tissues of Italian Large White and Italian Duroc pigs, Livest. Sci., 162, 15-22, 2014.

Brüssow, K. P., Schneider, F., Tuchscherer, A., Egerszegi, I., and Rátky, J.: Comparison of luteinizing hormone, leptin and progesterone levels in the systemic circulation (Vena jugularis) and near the ovarian circulation (Vena cava caudalis) during the oestrous cycle in Mangalica and Landrace gilts, J. Reprod. Develop., 54, 431-438, 2008.

Canovas, A., Quintanilla, R., Amills, M., and Pena, R. N.: Muscle transcriptomic profiles in pigs with divergent phenotypes for fatness traits, BMC Genomics, 11, 372, doi:10.1186/1471-216411-372, 2010.

Chen, Q. M., Wang, H., Zeng, Y. Q., and Chen, W.: Developmental changes and effect on intramuscular fat content of H-FABP and A-FABP mRNA expression in pigs, J. Appl. Genet., 54, 119123. 2013.

Chmurzynska, A.: The multigene family of fatty acid-binding proteins (FABPs): Function, structure and polymorphism, J. Appl. Genet., 47, 39-48, 2006.

Cho, E. S., Kwon, S. G., Kim, J. H., Park, D. H., Kim, T. W., Nam, J., Jang, I. S., Choi, J. S., Bang, W. Y., and Kim, C. W.: Study for the expression of adiponectin, fatty acid binding protein $(F A B P) 4$, stearoyl-CoA desaturase $(S C D)$ genes and the methylation of $S C D$ promoter in porcine muscle and fat tissues, Afr. J. Agric. Res., 6, 6425-6431, 2011.

Christoffersen, B. O., Gade, L. P., Golozoubova, V., Svendsen, O., and Raun, K.: Influence of castration-induced testosterone and estradiol deficiency on obesity and glucose metabolism in male Göttingen minipigs, Steroids, 75, 676-684, 2010.

Cirera, S., Jensen, M. S., Elbrond, V. S., Moesgaard, S. G., Christoffersen, B. O., Kadarmideen, H. N., Skovgaard, K., Bruun, C. V., Karlskov-Mortensen, P., Jorgensen, C. B., and Fredholm, M.: Expression studies of six human obesity-related genes in seven tissues from divergent pig breeds, Anim. Genet., 45, 59-66, 2014.

Damon, M., Louveau, I., Lefaucheur, L., Lebret, B., Vincent, A., Leroy, P., Sanchez, M. P., Herpin, P., and Gondret, F.: Number of intramuscular adipocytes and fatty acid binding protein- 4 content are significant indicators of intramuscular fat level in crossbred Large White $\times$ Duroc pigs, J. Anim. Sci., 84, 1083-1092, 2006.

Daniele, A., Cammarata, R., Masullo, M., Nerone, G., Finamore, F, D'Andrea, M., Pilla, F., and Oriani, G.: Analysis of adiponectin gene and comparison of its expression in two different pig breeds, Obesity, 16, 1869-1874, 2008.

Davoli, R., Gandolfi, G., Braglia, S., Comella, M., Zambonelli, P., Buttazzoni, L., and Russo, V.: New SNP of the porcine perilipin 2 (PLIN2) gene, association with carcass traits and expression analysis in skeletal muscle, Mol. Biol. Rep., 38, 1575-1583, 2011. 
De Rosa, A., Monaco, M. L., Nigro, E., Scudiero, O., D’Andrea, M., Pilla, F., Oriani, G., and Daniele, A.: Tissue-specific downregulation of the adiponectin "system": possible implications for fat accumulation tendency in the pig, Domest. Anim. Endocrin., 44, 131-138, 2013.

Ding, S. T., Liu, B. H., and Ko, Y. H.: Cloning and expression of porcine adiponectin and adiponectin receptor 1 and 2 genes in pigs, J. Anim. Sci., 82, 3162-3174, 2004.

Fernandez, X., Monin, G., Talmant, A., Mourot, J., and Lebret, B.: Influence of intramuscular fat content on the quality of pig meat: 1. Composition of the lipid fraction and sensory characteristics of $m$. longissimus lumborum, Meat Sci., 53, 59-65, 1999.

Fu, Y. F., Li, L., and Ren, S.: Effect of FTO expression and polymorphism on fat deposition in Suzhong pigs, Asian Australas. J. Anim. Sci., 26, 1365-1373, 2013.

Georgescu, S. E., Manea, M. A., Dinescu, S., and Costache, M.: Comparative study of leptin and leptin receptor gene expression in different swine breeds, Genet. Mol. Res., 13, 7140-7148, 2014.

Gerbens, F., Verburg, F. J., Van Moerkerk, H. T., Engel, B., Buist, W., Veerkamp, J. H., and te Pas, M. F.: Associations of heart and adipocyte fatty acid-binding protein gene expression with intramuscular fat content in pigs, J. Anim. Sci., 79, 347-354, 2001.

Holló, G., Seregi, J., Holló, I., Ender, K., and Nürnberg, K.: Meat and fat quality of Hungarian Mangalica breed Effect of different diets on carcass composition and fat quality of Mangalica pigs, Fleischwirtschaft, 89, 108-112, 2009.

Jacyno, E., Pietruszka, A., Kawecka, M., Biel, W., and KolodziejSkalska, A.: Phenotypic correlations of backfat thickness with meatiness traits, intramuscular fat, longissimus muscle cholesterol and fatty acid composition in pigs, S. Afr. J. Anim. Sci., 122-128, 2015.

Koncz, A., Petrási, Zs., Romvári, R., Donkó, T., Garamvölgyi, R., and Repa, I.: Comparative analysis of meat and fat tissue of Mangalica and meat-type hybrid pigs by means of Computerised Tomography, Acta Agr. Kaposváriensis, 18/S1, 180-187, 2014.
Lord, E., Ledoux, S., Murphy, B. D., Beaudry, D., and Palin, M. F.: Expression of adiponectin and its receptors in swine, J. Anim. Sci., 83, 565-578, 2005.

Luo, H. F., Wei, H. K., Huang, F. R., Zhou, Z., Jiang, S. W., and Peng, J.: The effect of linseed on intramuscular fat content and adipogenesis related genes in skeletal muscle of pigs, Lipids, 44, 999-1010, 2009.

Matsubara, M., Maruoka, S., and Katayose, S.: Inverse relationship between plasma adiponectin and leptin concentrations in normalweight and obese women, Eur. J. Endocrinol., 147, 173-180, 2002.

Mitchell, M., Armstrong, D. T., Robker, R. L., and Norman, R. J.: Adipokines: implications for female fertility and obesity, Reproduction, 130, 583-597, 2005.

Rátky, J, Egerszegi, I., Tóth, P., Keonuchan, S., Nagai, T., Kikuchi, K., Manabe, N., and Brüssow, K. P.: Saving genetic resources of native pigs in occidental and oriental countries - practical examples of the characterization and utilization of native pigs in Hungary and Laos, J. Reprod. Develop., 59, 437-441, 2013.

Ren, Z. Q., Xiong, Z. Y., Deng, C. Y., Zuo, B., Liu, Y. G., and Lei, M. G.: Age-dependent changes of differential gene expression profile in backfat tissue between hybrids and parents in pigs, Asian Australas. J. Anim. Sci., 18, 682-685, 2005.

Tempfli, K., Farkas, G., Simon, Z., and Bali Papp, Á.: Effects of prolactin receptor genotype on the litter size of Mangalica, Acta Vet. Hung., 59, 269-277, 2011.

Tempfli, K., Simon, Z., Kovács, B., Posgay, M., and Bali Papp, Á.: $P R L R, M C 4 R$ and LEP polymorphisms, and ADIPOQ, A-FABP and LEP expression in crossbred Mangalica pigs, J. Anim. Plant Sci., 25, 1746-1752, 2015.

Zhao, S. M., Ren, L. J., Chen, L., Zhang, X., Cheng, M. L., Li, W. Z., Zhang, Y. Y., and Gao, S. Z.: Differential expression of lipid metabolism related genes in porcine muscle tissue leading to different intramuscular fat deposition, Lipids, 44, 1029-1037, 2009. 